\title{
Maxillary Calcifying Epithelial Odontogenic Tumour
}

\author{
Souvagini Acharya, ${ }^{1}$ Nilamadhab Prusty, ${ }^{1}$ Choubarga Naik, ${ }^{2}$ Koushal Kumar $^{3}$ \\ 'Department of ENT, VSS Medical College, Burla, Odisha, India, ${ }^{2}$ Department of Dentistry, VSS Medical College, Burla, \\ Odisha, India, ${ }^{3}$ Department of Pathology, VSS Medical College, Burla, Odisha, India.
}

\section{ABSTRACT}

The calcifying epithelial odontogenic tumor is a benign, locally invasive, slow-growing neoplasm occurring as intraosseous (94\%) and extraosseous (6\%) variants and with a frequency of $1-2 \%$. Extraosseous variant is diagnosed slightly earlier than the intraosseous type. The intraosseous CEOT shows a maxilla:mandible site ratio of 1:2 and are mainly located in the premolar/molar region. Histologically, the CEOT is characterized by the occurrence of sheets, nests and masses of polyhedral, eosinophilic epithelial cells which may show cellular abnormalities including giant cell formation and nuclear pleomorphism. Some cells increase in size and produce a homogeneous, eosinophilic, 'amyloid-like' substance which may become calcified and which may be liberated as the cells break down. Enucleation with a margin of macroscopically normal tissue is the recommended treatment for CEOT involving the mandible. Maxillary CEOT are treated more aggressively, as they tend to grow more rapidly and do not usually remain well confined.

Keywords: calcifying epithelial odontogenic tumor; pindborgtumor; hemimandibulectomy.

\section{INTRODUCTION}

The calcifying epithelial odontogenic tumor (CEOT) also known as pindborg tumor was first introduced into scientific literature almost 50 years ago by Dr. J JPindborg. ${ }^{1,2}$ World Health Organization in 1992 classified it as a benign odontogenictumor, which is exclusively epithelial in its tissue of origin. The differential diagnosis for CEOT should include adenomatoidodontogenictumor (AOT), calcifying odontogenic cyst (COC), ameloblastic fibro odentoma (AFO), odontoma.

\section{CASE REPORT}

A 35 years old man presented to the ENT OPD with a huge swelling in right side of face measuring $15 \times 10$ $\mathrm{cm}$ extending from mandible up to right frontal region covering the eye. The swelling was not associated with pain, but was tender to touch and had progressively increased over a period of 2 years to attain the present size. The skin over the swelling was seen partly necrosed and puckered. During intraoral examination the hard palate on right side was seen pushed downwards.

FNAC was done which shown features of small round cell tumour. CT scan shows involvement of right maxilla without involving the inferior orbital rim with few areas of calcifications with contrast enhancement. The mass was excised enblocwith free margin by Weber-Fergusen incision and was sent for histopathological study. Palate defect was repaired by mobilising the temporalis muscle flap. Right mid-face defect was repaired by mobilising the forehead pedicle flap. Histopathological study confirmed the lesion to be CEOT.

Correspondence: Dr. Nilamadhaba Prusty, Department of ENT, VSS Medical College, Burla, Odisha, India. Email: nilamadhabprusty@ gmail.com, Phone: +91-9439482526. 


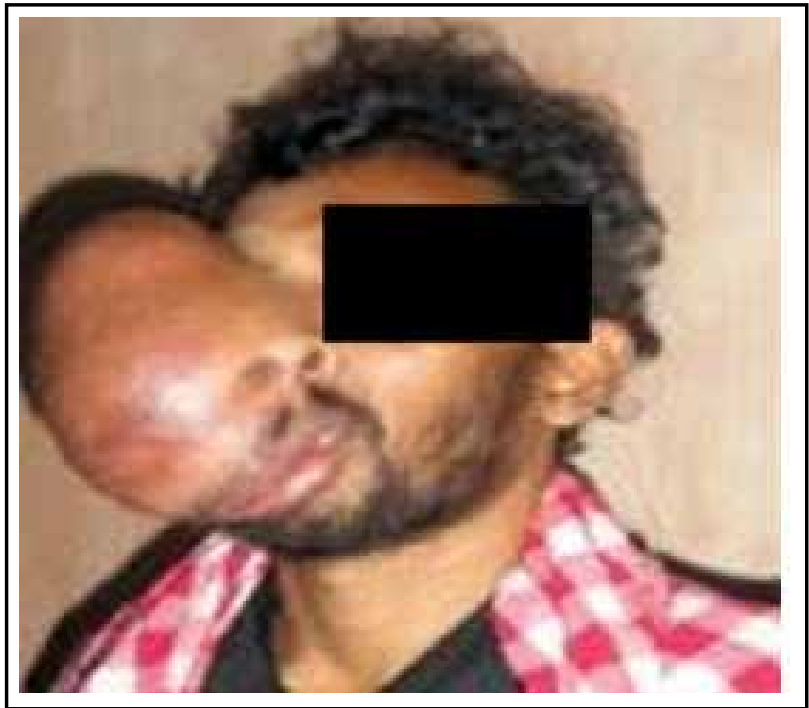

Figure 1. Post-Operative Photograph of the Patient.

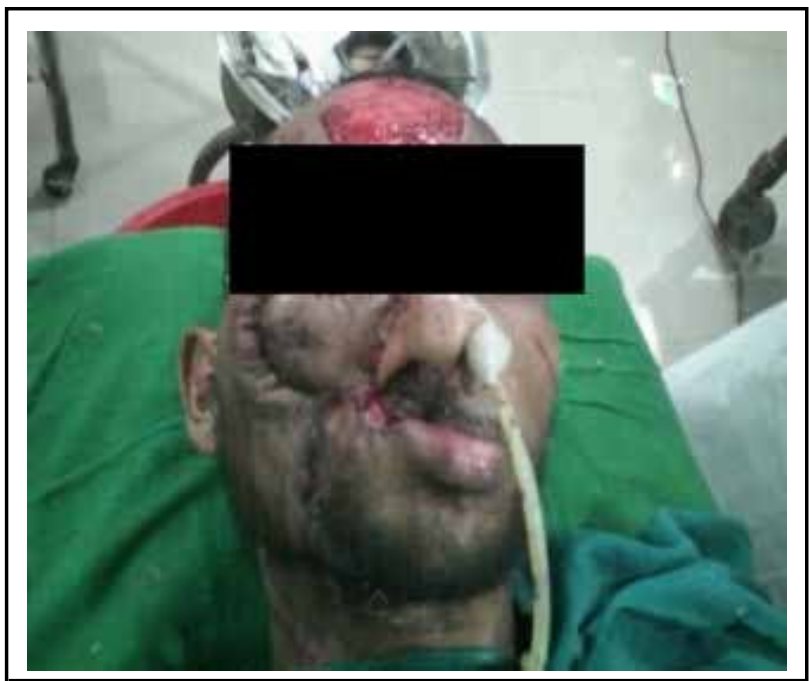

Figure 2.Post-Operative Photograph of the Patient.

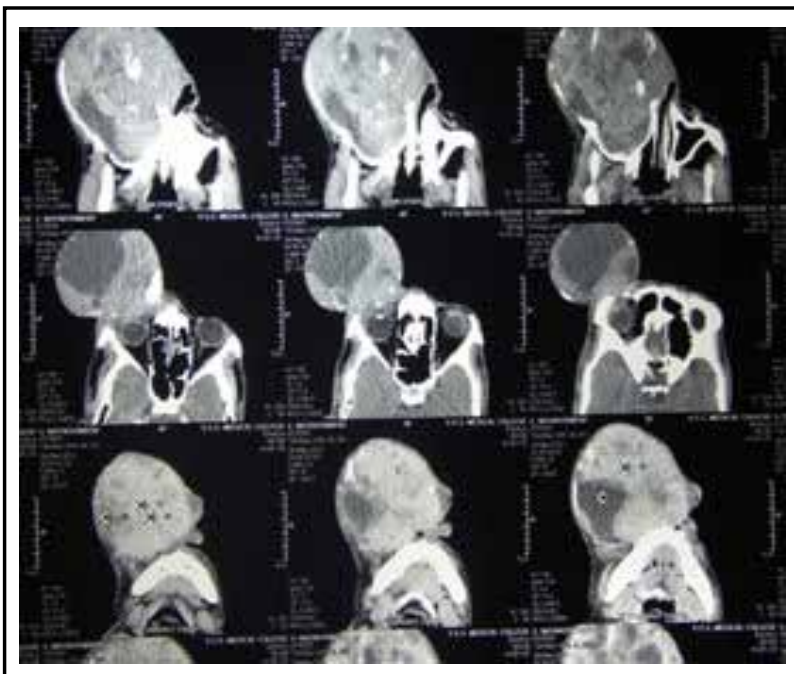

Figure 3.CT-Scan Showing Involvement of Maxilla

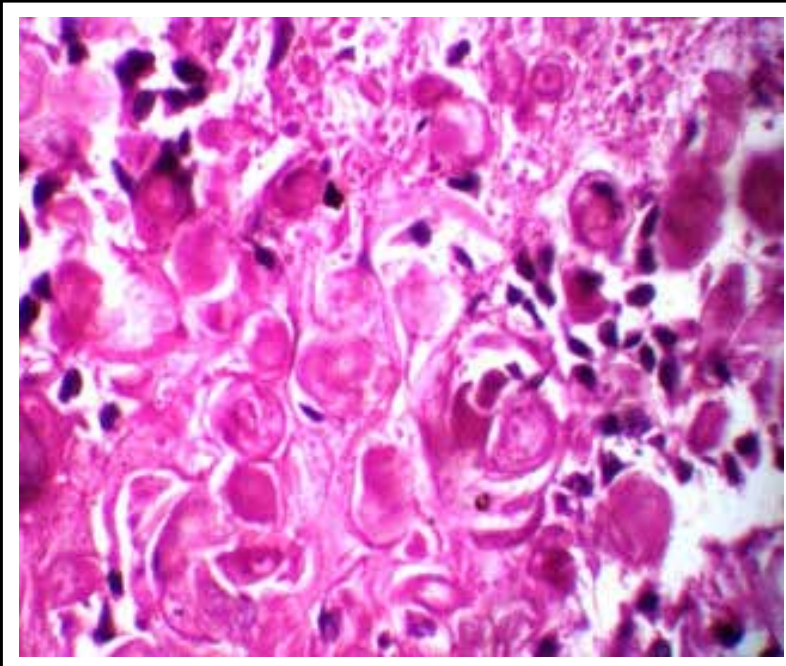

Figure 4. High Power View Depicting the Nuclear and Cellular Pleomorphism in the Tumor Cells.

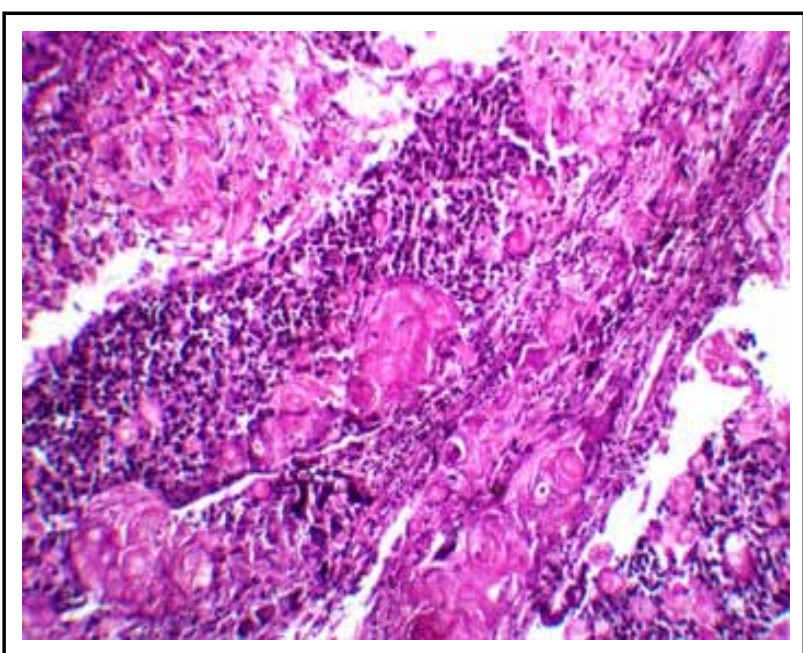

Figure 5. Hotopmicrograph Demonstrates Sheets of Polyhedral Cells Interspersed with Eosinophilic Material and Irregular Calcification.

\section{DISCUSSION}

Since its original description by Pindborg in 1955, the clinical features and histopathology of CEOT has been well described in literature. ${ }^{3,4}$ Classically, CEOT presents as a painless slow-growing mass in the mandible. The mean age of presentation is 40 years, with equal incidence in men and women. ${ }^{5}$ CEOT may present as an intraosseous (central) or extraosseous (peripheral) tumor. ${ }^{5}$ Intraosseous CEOT is the more common type, accounting for more than $85 \%$ of the cases and presenting most commonly at the mandible. The incidence of extraosseous CEOT is reported to be about $6 \%$. It occurs most commonly at the gingiva. ${ }^{5}$ The presentation of both intraosseous and extraosseous types is similar and both have similar histological features. Radiologically, intraosseous CEOT shows radiolucent areas with occasional calcification, while the extraosseous 
type shows bone erosion near the tumor. ${ }^{6}$ The histogenesis of the intraosseoustumor is believed to be from the stratum intermedium of enamel, whereas the extraosseous type is derived from dental lamina epithelial rests or the basal cells of gingival epithelium. ${ }^{7}$ Intraosseous CEOT is more aggressive, with a reported recurrence rate of $14 \%{ }^{6}$

Histopathologically, CEOT is characterized by the presence of epithelial cells, homogenous eosinophilic amyloidlike material, and calcification. The epithelial cells are arranged in nests and sheets and are polygonal, with clear to eosinophilic cytoplasm and vesicular nuclei having prominent nucleoli. A cribriform and pseudoglandular pattern of epithelial cells is also described. While moderate pleomorphism can be seen, necrosis and atypical mitosis is uncommon. Rounded, pale, eosinophilic material resembling amyloid is seen interspersed amidst tumor cells and is a characteristic finding of CEOT. Although the exact origin of this amyloid is not known it is believed to be derived from filamentous degradation of keratin filaments secreted by tumor epithelial cells. ${ }^{7}$ The presence of calcification is another defining feature of Pindborgtumor. The extent and shape of calcification can vary from minimal small round concretions to Liesegang rings and large aggregates.

According to Krolls and Pindborg, the presence or absence of calcification in CEOT has prognostic implications. A lack of calcification indicates less tumor differentiation and hence favors more chance of recurrence. ${ }^{8}$ Pindborg has also reported recurrence after removal in a CEOT that had minimal calcifications (Pindborg, J.J: Personal communication, 1974).

Total absence of calcification in CEOT has been reported in English language literature in only three cases previously. ${ }^{9-11}$ The first case was of a 68 -year-old man who presented with a slow-growing swelling in the mandible. ${ }^{9}$ In the second case, a 58-year-old man presented with an intraosseustumor in left maxillary canine and premolar region. Histopathology revealed small islands of epithelial cells, spherical eosinophilic deposits, and fibromyxoidstroma, along with S-100-positive Langerhans cells. ${ }^{10}$ The third case was a 61 -year-old man having a tumor in the anterior maxilla, which on histopathology showed total absence of calcification. ${ }^{11}$ While the first case did not show any evidence of recurrence 1 year after surgical excision, follow-up in the other two cases is not documented. The absence of calcification not only posed difficulties in diagnosing this rare tumor but also warranted an aggressive treatment approach.

Numerous surgical treatment modalities have been suggested, and the treatment plan is dependent on multiple factors such as size and location of neoplasm, general condition of patient and operator skill. Small, intrabony mandibular lesions with well-defined borders are treated by simple enucleation or curettage followed by judicious removal of a thin layer of bone adjacent to the tumor. ${ }^{11}$ Large tumors require aggressive approach by segmental resection, hemimandibulectomy and hemimaxillectomy, which causes bone discontinuity requiring reconstruction procedures such as grafting or distraction osteogenesis. ${ }^{12-14}$ Recurrence rate of $10-20 \%$ following conservative treatment is reported. ${ }^{14,15}$ Malignant transformation and metastasis is rare. ${ }^{16}$

\section{REFERENCE}

1. Pindborg JJ. Calcifying epithelial odontogenic tumour. Acta Pathol Microbiol Scand.1955;7:111.

2. 11. Pindborg JJ. A calcifying epithelial odontogenictumor. Cancer $1958 ; 11: 838-43$.

3. 6. Patiño B, Fernández-Alba J, Garcia-Rozado A, Martin R, López-Cedrún JL, Sanromán B. Calcifying epithelial odontogenic (pindborg) tumour: A series of 4 distinctive cases and a review of the literature. J Oral Maxillofac Surg. 2005;63:1361-8.

4. Maiorano E, Renne G, Tradati N, Viale G. Cytogical features of calcifying epithelial odontogenictumor (Pindborgtumor) with abundant cementum-like material. Virchows Arch. 2003;442 $: 107-10$.

5. El-Labban NG. Cementum-like material in a case of Pindborgtumor. J Oral Pathol Med. 1990;19:166-9.

6. 9. Hicks MJ, Flaitz CM, Wong ME, McDaniel RK, Cagle PT. Clear cell variant of calcifying epithelial odontogenictumor: Case report and review of the literature. Head Neck.1994;16:272-7.
7. Aviel-Ronen S, Liokumovich P, Rahima D, Polak-Charcon S, Goldberg I, Horowitz A. The amyloid deposit in calcifying epithelial odontogenictumor is immunoreactive for cytokeratins. Arch Pathol Lab Med. 2000;124:872-6.

8. Krolls SO, Pindborg JJ. Calcifying epithelial odontogenictumor.A survey of 23 cases and discussion of histomorphologic variations. Arch Pathol. 1974;98:206-10.

9. Aufdermaur M. Pindborg tumour. J Cancer Res ClinOncol. 1981;101:227-30.

10. Takata T, Ogawa I, Miyauchi M, Ijuhin N, Nikai H, Fujita M. Non-calcifying Pindborgtumor with Langerhans cells. J Oral Pathol Med. 1993;22:378-83.

11. Hafian H, Mauprivez C, Furon V, Pluot M, Lefevre B. Pindborg tumour: A poorly differentiated form without calcification. Rev StomatolChirMaxillofac. 2004;105:227-30. 
12. Bouckaert MM, Roubenheimer EJ, Jacobs FJ. Calcifying epithelial odontogenictumor with intracranial extension: Report of a case and review of literature. Oral Surg Oral Med Oral Pathol Oral RadiolEndod. 2000;90:656-62.

13. Philipsen HP, Reichart PA. Calcifying epithelial odontogenictumor: Biological profile based on 181 cases from the literature. Oral Oncol. 2000;36:17-26.

14. Chomette G, Auriol M, Guilbert F. Histoenzymological and ultrastructural study of a bifocal calcifying epithelial odontogenictumor: Characteristics of epithelial cells and histogenesis of amyloid-like material. Virchows Arch A PatholAnat Histopathol.1984;403:67-76.
15. Goldenberg D, Sciubba J, Koch W, Tufano RP. Malignant odontogenictumors: A 22-year experience. Laryngoscope. 2004;1 $14: 1770-4$

16. Cicconetti A, Tallarico M, Bartoli A, Ripari A, Maggiani F. Calcifying epithelial odontogenic (Pindborg) tumor: A clinical case. Minerva Stomatol. 2004;53:379-87. 